\title{
Geochemical Behavior of Trace- and Rare-Earth Elements in the Hydrothermal Alteration Facies of the Cijulang Area, West Java, Indonesia
}

\author{
Myo Min Tun 1* I Wayan Warmada², Arifudin Idrus², Agung Harijoko², Kotaro Yonezu ${ }^{3}$, \\ Koichiro Watanabe ${ }^{3}$
}

${ }^{1}$ Department of Geology, Yadanabon University, Amarapura Township, Mandalay, Mandalay Region, Myanmar ${ }^{2}$ Department of Geological Engineering, Faculty of Engineering, Gadjah Mada University, Yogyakarta, Indonesia ${ }^{3}$ Department of Earth Resources Engineering, Faculty of Engineering, Kyushu University, Motooka, Nishi-Ku, Fukuoka, Japan Email: *mintunmyo@gmail.com

How to cite this paper: Tun, M.M., Warmada, I.W., Idrus, A., Harijoko, A., Yonezu, K. and Watanabe, K. (2019) Geochemical Behavior of Trace- and Rare-Earth Elements in the Hydrothermal Alteration Facies of the Cijulang Area, West Java, Indonesia. Open Journal of Geology, 9, 278-294.

https://doi.org/10.4236/ojg.2019.95019

Received: April 9, 2019

Accepted: May 13, 2019

Published: May 16, 2019

Copyright $\odot 2019$ by author(s) and Scientific Research Publishing Inc. This work is licensed under the Creative Commons Attribution International License (CC BY 4.0).

http://creativecommons.org/licenses/by/4.0/

(c) (i) Open Access

\begin{abstract}
This study examines the behavior of trace- and rare-earth elements (REE) in different hydrothermal alteration facies (silicic, advanced argillic and argillic) of Cijulang high-sulfidation epithermal gold deposit, West Java, Indonesia. The results of the study indicate that remarkable differences in the behavior of trace elements and REE are observed in the studied alteration facies. All REE in the silicic facies are strongly depleted. In advanced argillic facies, Heavy rare-earth elements (HREE) are strongly depleted whereas light rare earth elements (LREE) are quite enriched. REE concentrations in the argillic facies show little or no variation with respect to fresh rock counterparts. A strong depletion of REE in the silicic facies is likely to be favored by the highly acidic nature of the hydrothermal fluids, the abundance of complexing ions such as $\mathrm{Cl}^{-}, \mathrm{F}^{-}$, and $\mathrm{SO}_{4}^{2-}$ in the hydrothermal solutions and the absence of the secondary minerals that can fix the REE in their crystal structures. An apparent immobility of LREE in advanced argillic facies is possibly due to the presence of alunite. The immobility of REE in the argillic facies suggests the higher $\mathrm{pH}$ of the fluids, the lower water/rock ratios and the presence of the phyllosilicates minerals.
\end{abstract}

\section{Keywords}

Cijulang, High-Sulfidation, Hydrothermal Alteration, Rare Earth Elements, Behavior 


\section{Introduction}

In the past, REE and high-field strength elements have been accepted as rather immobile elements, unaffected by hydrothermal alteration process and metamorphism. Recently it has been realized that REE could be mobilized under certain conditions. The detailed descriptions of REE mobility in the hydrothermal fluids and hydrothermally-altered rocks of some mineralized systems have been discussed elsewhere ([1]-[16]). The mobility of REE in the hydrothermal fluids is significantly controlled by low $\mathrm{pH}$, high water/rock ratios and the ability of complexing ions such as $\mathrm{CO}_{3}^{2-}, \mathrm{F}^{-}, \mathrm{Cl}^{-}, \mathrm{PO}_{4}^{3-}$ and $\mathrm{SO}_{4}^{2-}$ ([1] [7] [17]). In particular, they are preferentially complexed by $\mathrm{Cl}^{-}$and $\mathrm{SO}_{4}^{2-}$ in acid conditions [18] [19]. HREE are favorably concentrated in later products of hydrothermal systems as they form more stable complexes with some ligands and exist in solution longer than LREE ([20] [21]).

We examine the behavior of the trace and REE in the hydrothermal alteration of Cijulang high sulfidation epithermal gold deposit, West Java, Indonesia. The study on REE behavior was carried out in the alteration facies of silicic, advanced argillic, and argillic. The main objective of this study is to understand the physico-chemical conditions of hydrothermal fluids responsible for hypogene wall-rock alteration during the evolution of high-sulfidation epithermal system in the Cijulang area.

\section{Geological Setting}

The Islands of Java and Sumatra combined to form as a part of the Sunda-Banda magmatic arc which stretches from Aceh in the western part to Banda in the eastern part [22] (Figure 1). This magmatic arc, the longest of all magmatic arcs in Indonesia, has been created during Cenozoic due to the subduction of north-moving Indo-Australian Plate underneath the Southeast Asian Plate and tectonically active since Eocene ([23] [24]). The western segment which is located to the west of the central Java was developed on the continental crust whereas

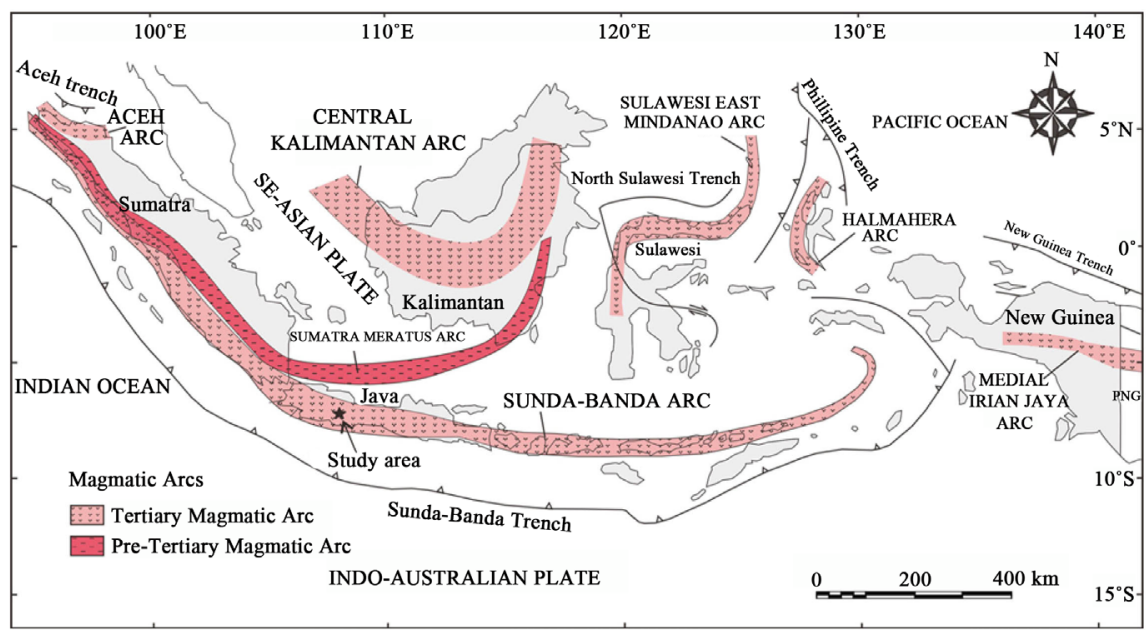

Figure 1. Map showing the distribution of magmatic arcs in Indonesia [22]. 
the eastern segment which is situated to the east of the central Java was built upon the thinner island arc crust [22].

The Sunda-Banda magmatic arc constitutes volcanics and volcaniclastic rocks of Tertiary to Quaternary age. They are sometimes intruded by smaller plutonic masses with similar composition as volcanics. Numerous and still-active calc-alkaline magmatism occur throughout the magmatic arc [23]. The volcanism of the entire Java arc has shifted from south to north over time ([25] [26]) which is evident by the E-W alignment of deeply dissected Miocene-Pliocene volcanic centers along the southern coast of Java and a parallel E-W alignment of juvenile and still active Quaternary volcanoes further north along the central Java. However, the magmatic affinities of the volcanics in the magmatic arc remained calc-alkaline with time until recent time ([27] [28]).

The Sunda-Banda Magmatic Arc served as a host for several hydrothermal deposits such as porphyry copper-gold, epithermal gold-silver, skarngold-copper, and volcanogenic massive sulfides. West Java is a well-known gold district in this magmatic arc and one of the most gold-producing areas in Indonesia. Present day operating gold mines are located in the three distinct regions of West Java: Bayah Dome Complex, Honje Igneous Complex and Southern Mountains. Recently several occurrences of epithermal gold and base metals mineralization have also been reported. Hence, much attention has been paid to these regions as they still stand as districts of future potential mineral resources. Cijulang is one of the interesting areas located in the Southern Mountains ([29] [30]) of West Java. Southern Mountains is regarded as the present-day forearc between the Quaternary volcanic chain and the Java Trench. It is comprised of volcanic and volcaniclastic rocks of Tertiary to Quaternary age.

Cijulang gold deposit was discovered by PT Aneka Tambang Tbk in 1996. Previous works ([31] [32]) indicated that gold mineralization in the Cijulang area shows typical features of high-sulfidation epithermal system by the presence of enargite-gold mineralization and accompanying acid sulfate alteration. Even though some researches and exploration works have been carried out in the Cijulang area, the behavior of REE and trace elements in different hydrothermal alteration facies and physico-chemical conditions of hydrothermal fluids during the evolution of high-sulfidation epithermal system have yet to be studied. Thus, the main objective of this study is to investigate the behavior of the REE and trace elements in the hydrothermal alteration facies of Cijulang area, West Java, Indonesia.

The local geology of the Cijulang area consists of andesite lava, lapilli tuff with minor crystal-lithic tuff, andesite and andesitic breccias (Figure 2). Andesite lava is regarded as a part of the Upper Oligocene to Middle Miocene Jampang Formation whereas lapilli tuff is considered to be a member rock of the Upper Miocene Koleberes Formation. Andesite and andesitic breccias belong to Mt. Kendeng Lava (Pleistocene). Geological structure in the study area is dominated by NE-SW and N-S trending strike-slip faults. The Cikahuripan Fault, the N-S trending dextral fault, played a significant role in the development of high sulfidation epithermal system in the research area (Figure 2). 


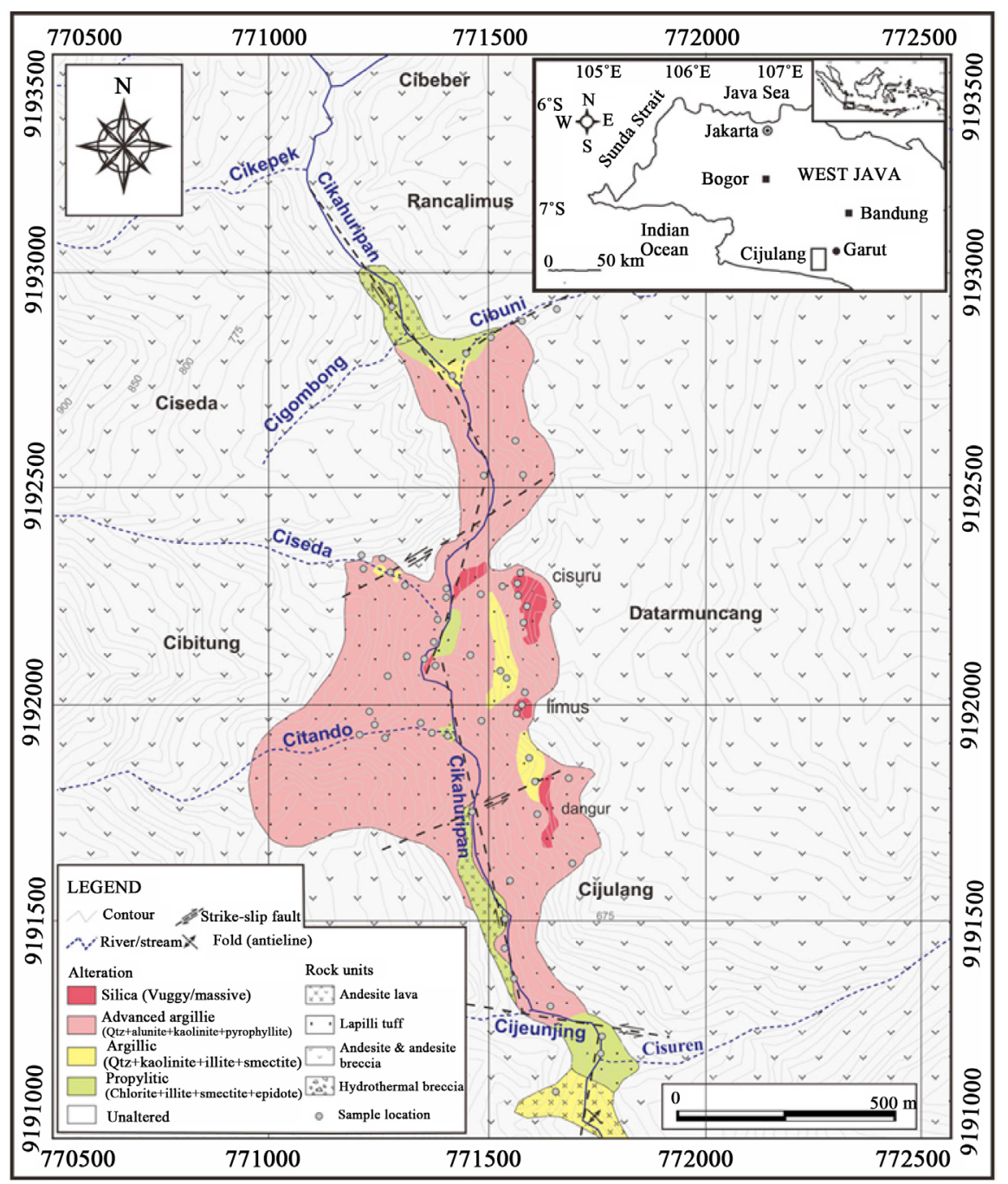

Figure 2. Map showing the geology and hydrothermal alteration of the Cijulang area, West Java, Indonesia.

\section{Hydrothermal Alteration}

In Cijulang area, hydrothermal alteration is associated with pyrite-enargite-gold mineralization and covers over an area of approximately $2 \mathrm{~km}$ long and $1 \mathrm{~km}$ wide north-south trending elongate zone (Figure 2). Hypogene alteration primarily occurs in lapilli tuff and andesite lava. Based on field investigation, petrological, and mineralogical studies, four different hydrothermal alteration facies are identified: Silicic, advanced argillic, argillic, and propylitic. A characteristic alteration sequence and zonation of advanced argillic, argillic and propylitic outward from silicic core has resulted from the progressive cooling and neutralization of hot acidic magmatic fluids [32].

Silicic alteration occurs in the lapilli tuff (Figure 3(a)) and consists of both vuggy and massive quartz. This alteration is well-recognized by weather-resistant bodies of quartz. Vuggy zone comprises residual silica remaining after removal of its reactive components such as primary minerals and fragments 


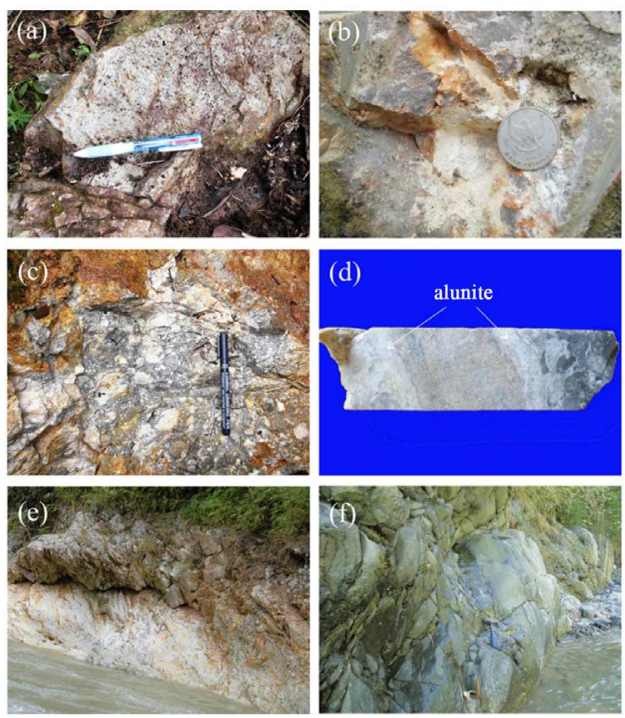

Figure 3. Various hydrothermal alteration types in Cijulang area. (a) vuggy silica alteration in lapilli tuff, (b) advanced argillic alteration in magmatic hydrothermal breccias, (c) argillic alteration in lapilli tuff, and (d) propylitic alteration in andesite lava.

of the host rock by leaching of highly acidic magmatic vapor [9]. The vuggy silica core is generally formed by initial leaching by hot, extremely acidic magmatic fluids (temperature $\sim 300^{\circ} \mathrm{C}$ and $\mathrm{pH}<2$ [33]) with subsequent silica deposition and recrystallization in the vugs, open spaces and the matrix resulting massive quartz. Vugs are sometimes filled with clays (kaolinite, dickite, and pyrophyllite) (Figure $3(b)$ ) and ores (pyrite and enargite). Silica zone often attains yellow or rusty color in places where oxidation of sulfides has taken place.

Advanced argillic alteration is the most widespread alteration and occurs in lapilli tuff and hydrothermal breccias (Figure 3(c)). In an outcrop, this alteration zone is strongly bleached and contains a variable amount of kaolinite, dickite, pyrophyllite, diaspore, illite and pyrite. Pyrophyllite, kaolinite and dickite are the dominant minerals in the outcrops whereas alunite is major constituents in the drill core sample (Figure 3(d)). Advanced argillic alteration occurs as massive replacement, fractures and vugs fillings (Figure $3(\mathrm{~d})$ ) in the host rock and as matrix in the magmatic hydrothermal breccia. The dominant mineral assemblages are quartz-pyrophyllite-kaolinite, quartz-dickite-pyrophyllite, quartz-kaolinite, quartz-alunite-dickite-pyrite, and quartz-alunite-kaolinite-pyrite.

Argillic alteration occurs as intermediate and discontinuous zones between advanced argillic and propylitic zones. It occurs in lapilli tuff and andesite lava. This zone is enriched in quartz and clay minerals such as kaolinite, illite, illite-smectite, smectite, muscovite, and chlorite. This alteration is quite pervasive and generally white and soft (Figure 3(e)). The common mineral assemblages are quartz-illite-kaolinite-pyrite and quartz-illite-montmorillonite-pyrite.

Propylitic alteration is the marginal facies of the hydrothermal alteration system and hosted by lapilli tuff and andesite lava (Figure 3(f)). It is characterized by quartz, chlorite, epidote, illite, smectite, pyrite, hematite, goethite, carbonate, 
and magnetite. In contrast to other alteration types, primary texture of the host rock is generally preserved. The common assemblage is quartz-chlorite-illiteepidote-calcite.

\section{Analytical Techniques}

A total of 75 samples, involving a spectrum of the least- to the most-altered rocks and fresh/un-altered rock from both surface and subsurface (drill cores section), were collected from several localities. Characteristics of the rocks such as lithology, mineralogy, and alteration of samples were examined in the field.

Mineralogical studies were carried out by optical microscopy in combination with X-ray (powder) diffraction (XRD) analysis. Bulk-rock and clay fraction samples $(<2 \mu \mathrm{m})$ were determined using a Rigaku RINT-2100 Diffractometer. The analysis was performed at a scan speed of $2^{\circ} / \mathrm{min}$ with $\mathrm{CuKa}$ radiation $(\lambda=$ $1.542 \AA$ ) from $2^{\circ}$ to $65^{\circ} / 2 \theta$. Count data for the random powder mounts and clay fractions were collected from $2^{\circ}$ to $65^{\circ} / 2 \theta$ and $2^{\circ}$ to $30^{\circ} / 2 \theta$ respectively. Major and elemental compositions were determined by X-Ray Fluorescence (XRF) Spectrometer under pressed pellets using a RIGAKU RIX-3100 (Series VR 25006). The X-ray machine is operated at $50 \mathrm{kV}$ and $50 \mathrm{~mA}$, Scanning speed: automatic and $4 \% \mathrm{~min}$ for the determination of the major element composition. For quality control, the standard sample JA-3 was used as standard sample.

The mineral composition of alteration minerals was determined using SHIMADZU SS-550 Scanning Electron Microscope equipped with a Genesis-2000 EDS Spectrometer. Analytical conditions were $15 \mathrm{kV}$ accelerating voltage, $10 \mathrm{~mA}$ beam current, and $3 \mu \mathrm{m}$ beam diameter. XRD and XRF analyses were performed at the laboratory of Economic Geology, Department of Earth Resources Engineering, Kyushu University, Japan whereas SEM-EDS and EPMA analyses were carried out at The Center for Advanced Instrumental Analysis, Kyushu University, Japan. Analyses for trace elements and REE were carried out for 12 samples taken from three different alteration zones and un-altered precursor rock by instrumental neutron activation analysis (INAA), Inductively Coupled Plasma (ICP) and Inductively Coupled Plasma Mass Spectrometry (ICP-MS) methods at ACME Laboratories, Canada. Trace elements and REE elements were reported on a $0.1 \mathrm{~g}$ sample and concentrations were determined following a lithium metaborate/tetraborate fusion and dilute nitric acid digestion.

Detection limits for all major oxides are $0.01 \mathrm{wt} \%$, except $\mathrm{MnO}, \mathrm{TiO}_{2}$ and $\mathrm{S}$ which are $0.001 \mathrm{wt} \%$. Detection limits for trace elements and REE are: Sc, Be, Co, Ni, Zn, Cu, Ga, Ge, Nb, Sn, W, 1 ppm; Rb, Sr, Y, Mo, 2 ppm; Ba, Se, 3 ppm; $\mathrm{Zr}, 4$ ppm; V, Pb, As, Cr, Ir, 5 ppm; Cr, 20 ppm; La, Ce, Nd, Sm, Gd, Tb, Dy, Ho, Er, Yb, Ta, Tl, Th, U, Sc, 0.1 ppm; In, Hf, Sb, 0.2 ppm; Ag, 0.3 ppm; Bi, 0.4 ppm; Cd, Sb, Cs, As, Br, 0.5 ppm; Lu, 0.04 ppm; Pr, Eu, Tm, 0.05 ppm; Au, 2 ppb. Loss on ignition (LOI) was determined for all samples by measuring the weight difference after ignition at $1000^{\circ} \mathrm{C}$. The results of chemical analyses were presented in Table 1. 
Table 1. Results of ICPMS analyses for different hydrothermally-altered and un-altered rocks from Cijulang area.

\begin{tabular}{|c|c|c|c|c|c|c|c|c|c|c|c|c|}
\hline \multirow[t]{2}{*}{ Sample } & \multicolumn{2}{|c|}{$\begin{array}{c}\text { Un-altered } \\
\text { precursor rock (lapillituff) }\end{array}$} & \multicolumn{4}{|c|}{$\begin{array}{l}\text { Argillic alteration facies } \\
\text { (lapillituff) }\end{array}$} & \multicolumn{4}{|c|}{$\begin{array}{l}\text { Advance argillic alteration facies } \\
\text { (lapillituff) }\end{array}$} & \multicolumn{2}{|c|}{$\begin{array}{l}\text { Silicic alteration } \\
\text { facies (lapillituff) }\end{array}$} \\
\hline & CUA-1 & CUA-2 & CA-1 & CA-2 & CA-3 & $\mathrm{CA}-4$ & CAD-1 & CAD-2 & CAD-3 & CAD-4 & CSI-1 & CSI-2 \\
\hline \multicolumn{13}{|c|}{ Major element (wt.\%) } \\
\hline $\mathrm{SiO}_{2}$ & 55.54 & 59.7 & 78.21 & 74.38 & 46.39 & 72.3 & 90.74 & 77.94 & 74.76 & 68.22 & 94.55 & 90.48 \\
\hline $\mathrm{Al}_{2} \mathrm{O}_{3}$ & 16.64 & 16.19 & 12.3 & 13.14 & 16.99 & 17.69 & 5.56 & 13.56 & 14.58 & 16.85 & 0.67 & 2.79 \\
\hline $\mathrm{Fe}_{2} \mathrm{O}_{3}$ & 8.68 & 7.96 & 1.63 & 0.78 & 9.83 & 0.52 & 1.25 & 0.96 & 1.93 & 4.33 & 2.25 & 1.75 \\
\hline $\mathrm{CaO}$ & 7.58 & 6.57 & 0.09 & 2.24 & 7.82 & 0.12 & 0.07 & 0.09 & 0.13 & 0.12 & 0.12 & 1.25 \\
\hline $\mathrm{Na}_{2} \mathrm{O}$ & 2.85 & 3.3 & 1.69 & 0.88 & 2.69 & 0.08 & 0.02 & 0.02 & 0.04 & 0.03 & 0.03 & 0.44 \\
\hline $\mathrm{K}_{2} \mathrm{O}$ & 1.2 & 1.3 & 1.66 & 2.13 & 0.59 & 1.23 & 0.03 & 0.04 & 0.09 & 0.07 & 0.03 & 0.2 \\
\hline $\mathrm{MgO}$ & 4.23 & 2.65 & 0.19 & 0.22 & 5.2 & 0.11 & 0.02 & 0.01 & 0.03 & 0.03 & 0.02 & 0.58 \\
\hline $\mathrm{MnO}$ & 0.166 & 0.151 & 0.006 & 0.024 & 0.191 & 0.007 & 0.004 & 0.004 & 0.004 & 0.006 & 0.012 & 0.028 \\
\hline $\mathrm{TiO}_{2}$ & 0.837 & 0.815 & 0.283 & 0.302 & 0.884 & 0.619 & 0.496 & 0.615 & 0.626 & 0.438 & 0.421 & 0.43 \\
\hline $\mathrm{P}_{2} \mathrm{O}_{5}$ & 0.16 & 0.15 & $<0.01$ & 0.01 & 0.15 & 0.13 & 0.1 & 0.18 & 0.22 & 0.18 & 0.07 & 0.03 \\
\hline L.O.I. & 1.21 & 1.4 & 4.23 & 5.83 & 8.88 & 6.13 & 2.48 & 5.5 & 6.72 & 9.12 & 1.59 & 0.56 \\
\hline Total & 99.08 & 100.2 & 100.3 & 99.94 & 99.6 & 98.92 & 100.8 & 98.91 & 99.12 & 99.38 & 99.75 & 98.54 \\
\hline \multicolumn{13}{|c|}{ Trace element (ppm) } \\
\hline S & 0.035 & 0.023 & 1.1 & 0.057 & 0.025 & 0.012 & 0.064 & 0.067 & 1.41 & 3.59 & 1.1 & 0.096 \\
\hline V & 206 & 161 & 14 & 21 & 244 & 137 & 34 & 107 & 86 & 105 & 24 & 38 \\
\hline $\mathrm{Sc}$ & 25 & 25 & 11 & 12 & 32 & 12 & 4 & 11 & 7 & 8 & 5 & 7 \\
\hline $\mathrm{Be}$ & 1 & 1 & bdl & bdl & bdl & 1 & 1 & bdl & bdl & bdl & bdl & bdl \\
\hline $\mathrm{Cr}$ & 30 & bdl & bdl & bdl & 200 & bdl & bdl & bdl & bdl & bdl & bdl & bdl \\
\hline Co & 24 & 18 & 2 & 1 & 30 & bdl & bdl & bdl & 4 & 8 & bdl & 4 \\
\hline $\mathrm{Ni}$ & 22 & 13 & bdl & bdl & 42 & bdl & bdl & bdl & 2 & 3 & bdl & 5 \\
\hline $\mathrm{Cu}$ & 78 & 49 & 5 & 3 & 22 & 19 & 22 & 12 & 18 & 62 & 58 & 28 \\
\hline $\mathrm{Zn}$ & 66 & 76 & 47 & 18 & 66 & 9 & 5 & 4 & 15 & 31 & 4 & 14 \\
\hline $\mathrm{Rb}$ & 52 & 54 & 40 & 59 & 15 & 45 & bdl & bdl & bdl & 2 & bdl & 9 \\
\hline $\mathrm{Sr}$ & 251 & 208 & 52 & 110 & 677 & 296 & 333 & 816 & 955 & 469 & 60 & 55 \\
\hline $\mathrm{Y}$ & 24 & 29 & 27 & 36 & 16 & 19 & 5 & 6 & 8 & 8 & 3 & 5 \\
\hline $\mathrm{Nb}$ & 3 & 4 & 1 & 2 & 1 & 3 & 3 & 2 & 3 & 2 & 2 & 2 \\
\hline $\mathrm{Ba}$ & 146 & 211 & 137 & 220 & 113 & 143 & 101 & 238 & 411 & 363 & 119 & 38 \\
\hline $\mathrm{W}$ & $<1$ & $<1$ & 1 & bdl & bdl & bdl & 3 & 15 & 4 & 2 & 3 & bdl \\
\hline $\mathrm{Pb}$ & 5 & 8 & bdl & 6 & bdl & 22 & 638 & 910 & 220 & 222 & 225 & 109 \\
\hline Th & 4.8 & 4.8 & 2.2 & 2.2 & 1.1 & 6.9 & 10 & 8.4 & 4.8 & 6.6 & 6.6 & 4.7 \\
\hline $\mathrm{U}$ & 1.2 & 1 & 0.6 & 0.5 & 0.2 & 2 & 1.8 & 3.4 & 1.2 & 2.1 & 1.9 & 1.5 \\
\hline $\mathrm{Zr}$ & 106 & 113 & 121 & 118 & 42 & 86 & 86 & 72 & 109 & 65 & 86 & 78 \\
\hline
\end{tabular}




\section{Continued}

\begin{tabular}{|c|c|c|c|c|c|c|c|c|c|c|c|c|}
\hline As & 5.7 & 13 & 22.7 & 14 & 4 & 1050 & 169 & 101 & 23.7 & 59.2 & 272 & 24 \\
\hline $\mathrm{Sb}$ & $<0.5$ & $<0.5$ & 2.8 & 1.4 & 0.9 & 18.6 & 19.8 & 19.6 & 1.8 & 6.7 & 33.7 & 18.4 \\
\hline $\mathrm{Ga}$ & 17 & 18 & 13 & 14 & 16 & 19 & 19 & 28 & 30 & 18 & 2 & 4 \\
\hline $\mathrm{Ge}$ & 2 & 2 & 1 & 1 & 2 & 3 & 3 & 3 & 2 & 3 & 1 & 1 \\
\hline Sn & 1 & 1 & bdl & 1 & bdl & 2 & 33 & 8 & 2 & bdl & 22 & 22 \\
\hline $\mathrm{Sb}$ & $<0.2$ & $<0.2$ & 2.5 & 0.7 & $<0.2$ & 17.3 & 18.1 & 16.8 & 2.1 & 9.1 & 36.6 & 17.6 \\
\hline $\mathrm{Bi}$ & $<0.4$ & $<0.4$ & $<0.4$ & $<0.4$ & $<0.4$ & 0.9 & 34.9 & 14.8 & 5.7 & 1.6 & 132 & 27.1 \\
\hline $\mathrm{Br}$ & $<0.5$ & $<0.5$ & $<0.5$ & $<0.5$ & $<0.5$ & $<0.5$ & $<0.5$ & $<0.5$ & $<0.5$ & $<0.5$ & $<0.5$ & $<0.5$ \\
\hline $\mathrm{Cr}$ & 49 & 24 & $<5$ & 9 & 185 & $<5$ & 17 & 21 & 15 & 12 & 18 & 6 \\
\hline Ir & $<5$ & $<5$ & $<5$ & $<5$ & $<5$ & $<5$ & $<5$ & $<5$ & $<5$ & $<5$ & $<5$ & $<5$ \\
\hline Sc & 27.5 & 28 & 11.3 & 12.3 & 31 & 11.6 & 4.6 & 10.8 & 7.8 & 9.5 & 6.4 & 7.8 \\
\hline $\mathrm{Tl}$ & 0.1 & 0.2 & 0.3 & 0.3 & bdl & 1 & 0.2 & bdl & bdl & bdl & 1.6 & bdl \\
\hline $\mathrm{Hf}$ & 2.9 & 3.2 & 3.4 & 3.6 & 1.3 & 1.8 & 2.2 & 2.2 & 2.9 & 1.9 & 2.3 & 2.2 \\
\hline $\mathrm{Ta}$ & 0.2 & 0.7 & 0.1 & 0.1 & bdl & 0.3 & 0.3 & 0.2 & 0.2 & 0.2 & 0.3 & 0.2 \\
\hline \multicolumn{13}{|c|}{ REE (ppm) } \\
\hline $\mathrm{La}$ & 12.3 & 14.7 & 9 & 10.5 & 6.1 & 14.2 & 49.5 & 20.5 & 14.6 & 15.8 & 13.3 & 9.7 \\
\hline $\mathrm{Ce}$ & 27.1 & 30.3 & 21.5 & 24.7 & 13.4 & 28.1 & 101 & 40.6 & 30.4 & 32.8 & 25.1 & 18.5 \\
\hline $\operatorname{Pr}$ & 3.69 & 4.1 & 3.1 & 3.52 & 1.93 & 3.24 & 12.5 & 4.43 & 3.7 & 3.99 & 2.71 & 2.11 \\
\hline $\mathrm{Nd}$ & 15.9 & 17.5 & 14.4 & 17 & 9.4 & 12.1 & 47 & 18 & 14.8 & 15.4 & 10.3 & 8.1 \\
\hline $\mathrm{Sm}$ & 3.8 & 4.5 & 3.6 & 4.4 & 2.6 & 2.4 & 7.4 & 3.4 & 2.9 & 3 & 1.7 & 1.9 \\
\hline $\mathrm{Eu}$ & 1.01 & 1.16 & 0.79 & 1.19 & 0.89 & 0.76 & 1.39 & 0.97 & 0.86 & 0.79 & 0.41 & 0.52 \\
\hline $\mathrm{Gd}$ & 4 & 4.5 & 3.6 & 4.7 & 2.7 & 2.4 & 3.3 & 2.8 & 1.8 & 2.3 & 1.2 & 1.7 \\
\hline $\mathrm{Tb}$ & 0.7 & 0.8 & 0.7 & 0.9 & 0.5 & 0.4 & 0.3 & 0.3 & 0.2 & 0.3 & 0.1 & 0.3 \\
\hline Dy & 4.4 & 5 & 4.2 & 5.6 & 2.9 & 2.9 & 1.1 & 1.3 & 1.4 & 1.6 & 0.8 & 1.4 \\
\hline Ho & 0.9 & 1 & 0.9 & 1.2 & 0.6 & 0.6 & 0.2 & 0.2 & 0.3 & 0.3 & 0.1 & 0.2 \\
\hline Er & 2.6 & 3.1 & 2.9 & 3.7 & 1.5 & 1.5 & 0.6 & 0.6 & 1 & 0.9 & 0.4 & 0.6 \\
\hline $\mathrm{Tm}$ & 0.42 & 0.49 & 0.5 & 0.58 & 0.23 & 0.22 & 0.09 & 0.1 & 0.17 & 0.13 & 0.08 & 0.1 \\
\hline $\mathrm{Yb}$ & 2.7 & 3.4 & 3.4 & 4 & 1.5 & 1.5 & 0.6 & 0.8 & 1.4 & 0.8 & 0.6 & 0.7 \\
\hline $\mathrm{Lu}$ & 0.4 & 0.5 & 0.52 & 0.59 & 0.22 & 0.21 & 0.11 & 0.12 & 0.23 & 0.13 & 0.09 & 0.11 \\
\hline$\Sigma \mathrm{REE}$ & 79.92 & 91.05 & 69.11 & 82.58 & 44.47 & 70.53 & 225.09 & 94.12 & 73.76 & 78.24 & 56.89 & 45.94 \\
\hline$(\mathrm{La} / \mathrm{Sm}) \mathrm{cn}$ & 2.32 & 2.34 & 1.79 & 1.71 & 1.68 & 4.24 & 4.80 & 4.32 & 3.61 & 3.78 & 5.61 & 3.66 \\
\hline$(\mathrm{La} / \mathrm{Yb}) \mathrm{cn}$ & 3.27 & 3.10 & 1.90 & 1.88 & 2.92 & 6.79 & 59.18 & 18.38 & 7.48 & 14.17 & 15.90 & 9.94 \\
\hline$(\mathrm{Tb} / \mathrm{Yb}) \mathrm{cn}$ & 1.18 & 1.07 & 0.94 & 1.02 & 1.52 & 1.21 & 2.27 & 1.70 & 0.65 & 1.70 & 0.76 & 1.95 \\
\hline $\mathrm{Eu} / \mathrm{Eu}^{*}$ & 0.79 & 0.79 & 0.67 & 0.80 & 1.03 & 0.97 & 0.86 & 0.96 & 1.15 & 0.92 & 0.88 & 0.88 \\
\hline
\end{tabular}

Note: L.O.I.: Loss on ignition; bdl: Below detection limit. 


\section{Results}

\subsection{The Behavior of the REE and Other Trace Elements}

Abundances of REE in studied samples from three different hydrothermal alteration facies (silicic, advanced argillic, and argillic) and un-altered rocks were normalized to chondrite values [34] and the resulting REE patterns of silicic (CSI-1 and CSI-2), advanced argillic (CAD-1, CAD-2, CAD-3 and CAD-4) and argillic facies rocks (CA-1, CA-2, CA-3 and CA-4) were compared with those of un-altered rocks (CUA-1 and CUA-2) which are considered to be the precursor rocks of hydrothermal alteration (Figures 4(a)-(c)). X-ray diffraction patterns of three different alteration facies are also shown (Figures 5(a)-(f)). The chondrite-normalized REE patterns of the un-altered volcaniclastic rocks indicate variable enrichment of LREEs with respect to HREEs and exhibit negative Eu anomalies which are typical characteristics of the average upper continental crust [35].

The ratios of $(\mathrm{La} / \mathrm{Sm}) \mathrm{cn},(\mathrm{La} / \mathrm{Yb}) \mathrm{cn},(\mathrm{Tb} / \mathrm{Yb}) \mathrm{cn}$ and $\left(\mathrm{Eu} / \mathrm{Eu}^{*}\right) \mathrm{cn}$ were calculated for the different alteration facies and the precursor rocks (Table 1). Comparisons were made between precursor rocks and each alteration facies in order to understand the possible fractionation processes where REE could have been encountered during hydrothermal alteration (Figures $6(\mathrm{a})-(\mathrm{d})$ ). $(\mathrm{La} / \mathrm{Yb}) \mathrm{cn}$ ratio was calculated in order to observe the enrichment of LREE over HREE. Fractionation among LREE was indicated by $(\mathrm{La} / \mathrm{Sm}) \mathrm{cn}$ and those between MREE and HREE were expressed by $(\mathrm{Tb} / \mathrm{Yb}) \mathrm{cn}$. $\left(\mathrm{Eu} / \mathrm{Eu}^{*}\right) \mathrm{cn}$ ratio was also calculated by using the equation $\left(\mathrm{Eu} / \mathrm{Eu}^{*}=\mathrm{Eu} \sqrt{S m_{N}-G d_{N}}\right)$. The geochemical behavior of REE and their ratios will be discussed in the following sections.

\subsubsection{Silicic Alteration}

As a result of strong acid leaching and mobilization of almost all oxides and elements, silicic alteration facies rocks are characterized by quartz (Figure 5(a)). REEs in this facies are strongly depleted if compared to the un-altered precursor rocks (Figure 4(a)). A strong depletion is more pronounced in MREE and HREE (Figure 4(a)). The degree of impoverishment of HREE is related to the degree of silicification as the most intensely-silicified rocks seem to be characterized by higher depletion of HREE.

Silicic facies is characterized by high ratio of $(\mathrm{La} / \mathrm{Sm}) \mathrm{cn}$, moderately high ratio of $(\mathrm{Tb} / \mathrm{Yb}) \mathrm{cn}$ and low ratios of $(\mathrm{La} / \mathrm{Yb}) \mathrm{cn}$ and $\left(\mathrm{Eu} / \mathrm{Eu}^{*}\right) \mathrm{cn}$ (Figure 6). A strong depletion of all REEs in this facies could be explained by the very low $\mathrm{pH}$ condition [10] and the abundances of complexing ions $\left(\mathrm{Cl}^{-}, \mathrm{F}^{-}\right.$, and $\left.\mathrm{SO}_{4}^{2-}\right)$ in the hydrothermal solutions ([1] [2] [17] [18]). The depletion of REEs might also be favored by the absence of secondary minerals that can host the REE in their structures.

\subsubsection{Advanced Argillic Alteration}

Based on the result of XRD analysis, advanced argillic facies rocks are characterized by alunite, pyrophyllite, kaolinite and dickite (Figures 5(b)-(d)). On the 


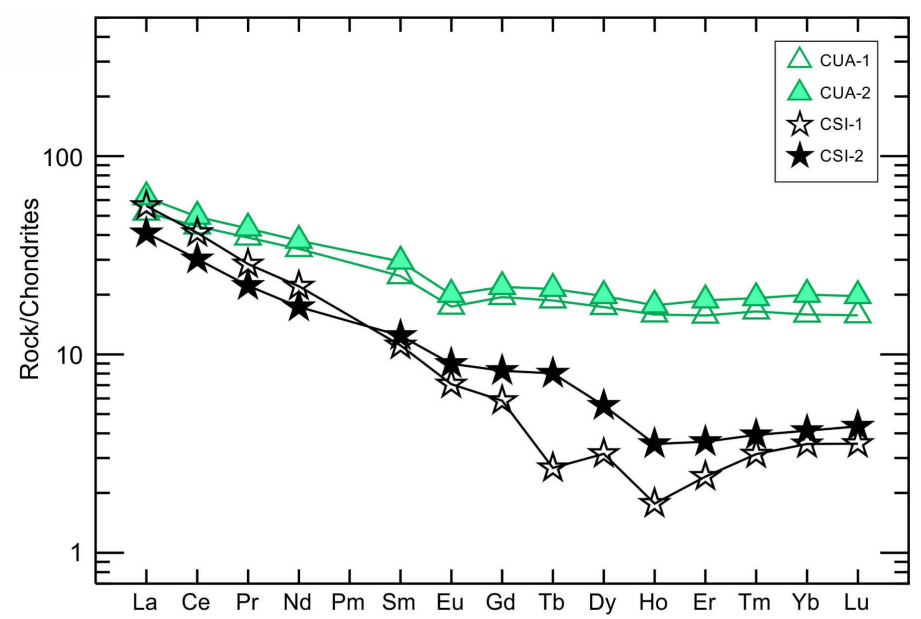

(a)

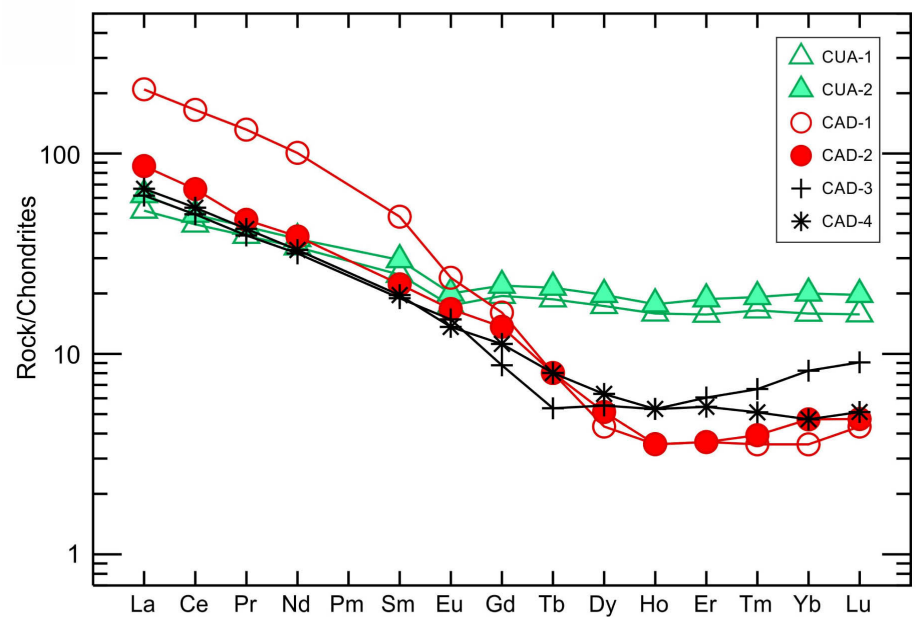

(b)

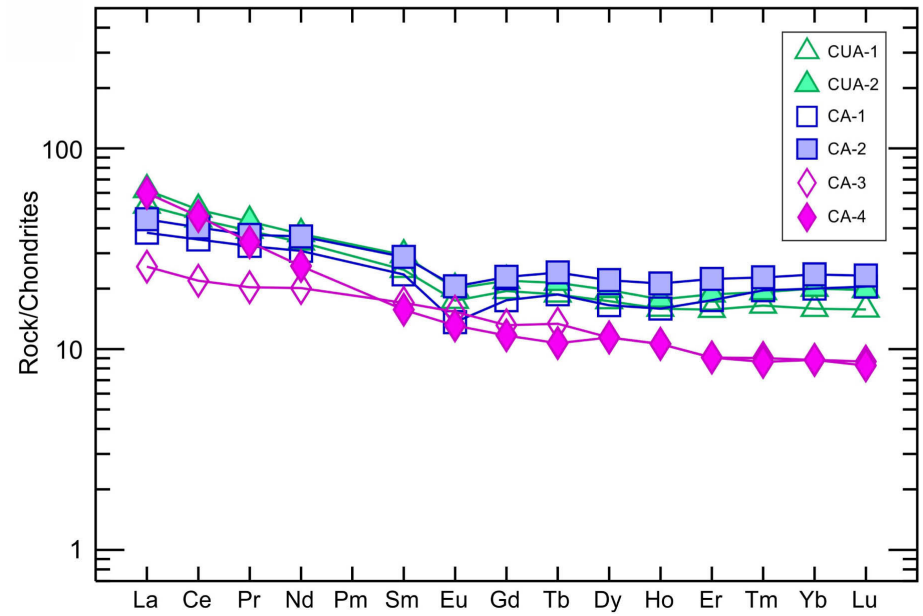

(c)

Figure 4. Chondrite-normalized REE patterns the un-altered rocks (CUA-1 and CUA-2) and hydrothermally-altered rocks. (a) silicic alteration (CSI-1 and CSI-2), (b) advanced argillic alteration (CAD-1, CAD-2, CAD-3 and CAD-4), (c) argillic alteration (CA-1, CA-2, CA-3 and CA-4). Data in the figures are from Table 1; normalization values are taken from Sun and McDonough [34]. 


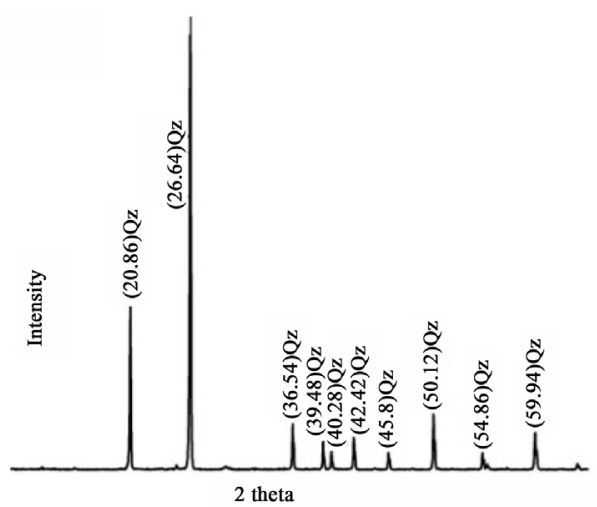

(a)

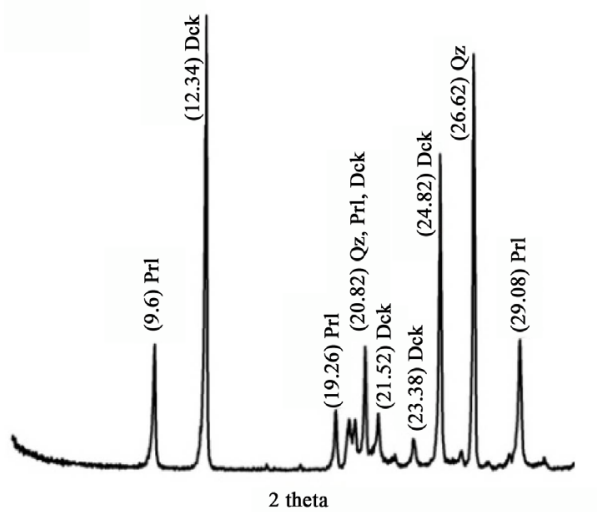

(c)

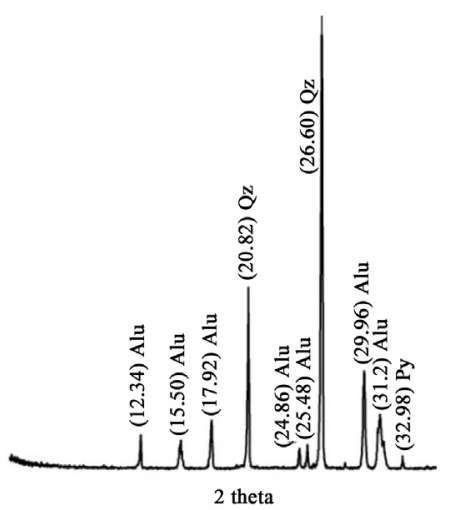

(b)

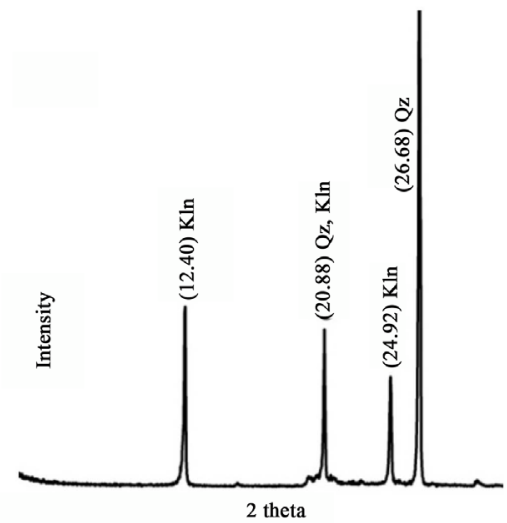

(d)

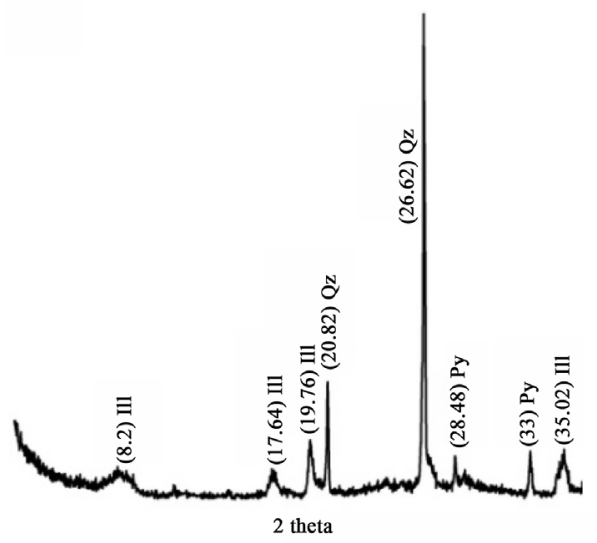

(e)

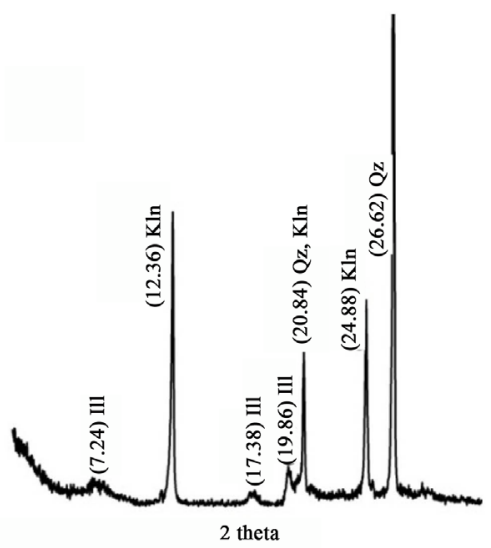

(f)

Figure 5. The result of XRD analyses for different alteration facies. (a) silicic alteration; ((b), (c) and (d)) advanced argillic alteration; (e) and (f) argillic alteration. Mineral abbreviation: Qz-quartz; Alu-alunite; Py-pyrite; Prl-pyrophyllite; Dck-dickite; Kln-kaolinite; Ilt-illite.

chondrite-normalized REE diagram, this facies rocks show LREE enrichment and its enrichment factor reaches about 110 times of chondritic level in the sample CAA1 (Figure 4(b)).

In contrast, both MREE and HREE concentrations are strongly depleted in this facies rocks. The $(\mathrm{La} / \mathrm{Yb}) \mathrm{cn}$ ratios are quite high, whereas $(\mathrm{La} / \mathrm{Sm}) \mathrm{cn}$, $(\mathrm{Tb} / \mathrm{Yb}) \mathrm{cn}$ and $\left(\mathrm{Eu} / \mathrm{Eu}^{*}\right) \mathrm{cn}$ ratios are moderately high (Figure 6). Fractionation 

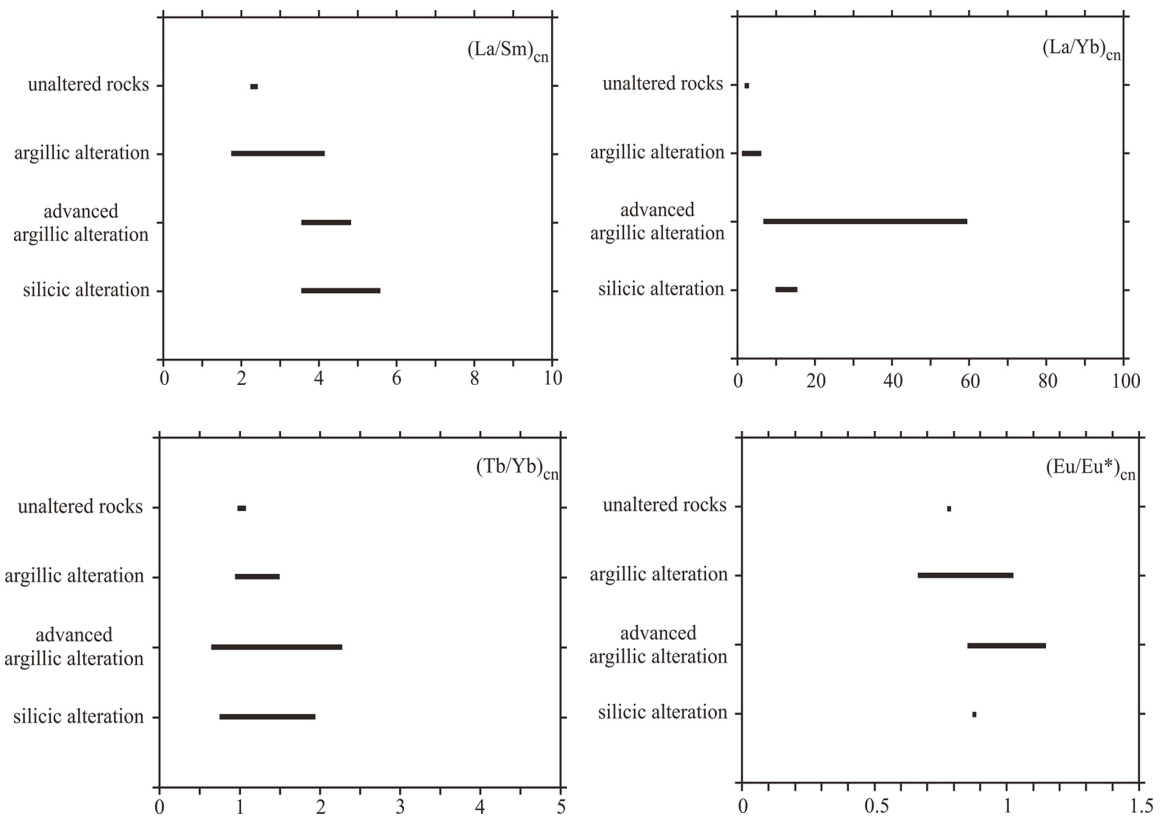

Figure 6. Variations in $(\mathrm{La} / \mathrm{Sm}) \mathrm{cn},(\mathrm{La} / \mathrm{Yb}) \mathrm{cn},(\mathrm{Tb} / \mathrm{Yb}) \mathrm{cn}$ ratios displaying REE fractionation in the hydrothermally-altered rock compared to un-altered equivalent original rocks. The $\left(\mathrm{Eu} / \mathrm{Eu}^{*}\right) \mathrm{cn}$ ratio shows the variation of $\mathrm{Eu}$ anomaly. $\left(\mathrm{Eu} / \mathrm{Eu}^{*}=\mathrm{Eu} \times\right.$ $\left.\sqrt{S m_{N}-G d_{N}}\right)$.

of REE is quite obvious in this facies. Hydrothermal fluids responsible for the development of the advanced argillic alteration were derived from the partial neutralization and dilution of fluids which involved in the silicic alteration. The presence of alunite indicates a high activity of the sulfate ion in the hydrothermal solutions [36].

\subsubsection{Argillic Alteration}

The rocks of argillic alteration facies are composed of quartz; illite and kaolinite (Figure 5(e) and Figure 5(f)). REE patterns of this facies rocks do not show significant variation with respect to un-altered precursor rock (Figure 4(c)). This is also evident by the higher ratios of $(\mathrm{La} / \mathrm{Sm}) \mathrm{cn}$ in the studied samples (Figure 6).

\subsubsection{Isocon Method}

Isocon method of Grant [37] was applied in order to determine the mobility of elements in different alteration facies with respect to precursor rock, as the chemical analyses of an original and an altered rock cannot be directly compared to estimate gains and losses until a reference frame or assumption has been made [38]. In this study, some components are assumed to be remained as immobile during alteration. Selected elements were plotted against $\mathrm{TiO}_{2}$ (Figure not shown) and those with a correlation coefficient $r \geq 0.6$ were considered as immobile. $\mathrm{La}, \mathrm{Pr}, \mathrm{Nd}, \mathrm{Ho}, \mathrm{Tm}, \mathrm{Lu}$, and $\mathrm{P}_{2} \mathrm{O}_{5}$ were found to be immobile and are used as mass changes indicators. The geometry of isocon diagram is such that the elements below the straight isocon line are depleted whereas those above are enriched by the hydrothermal alteration (Figures 7(a)-(c)). 

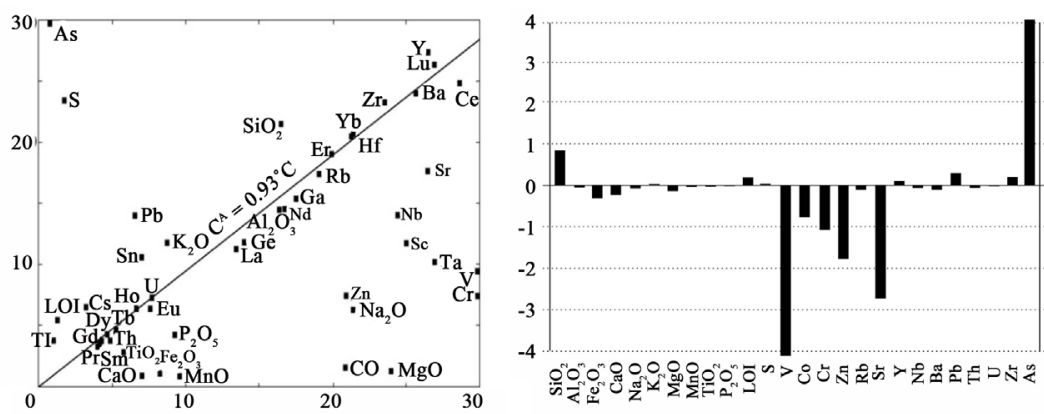

(a)
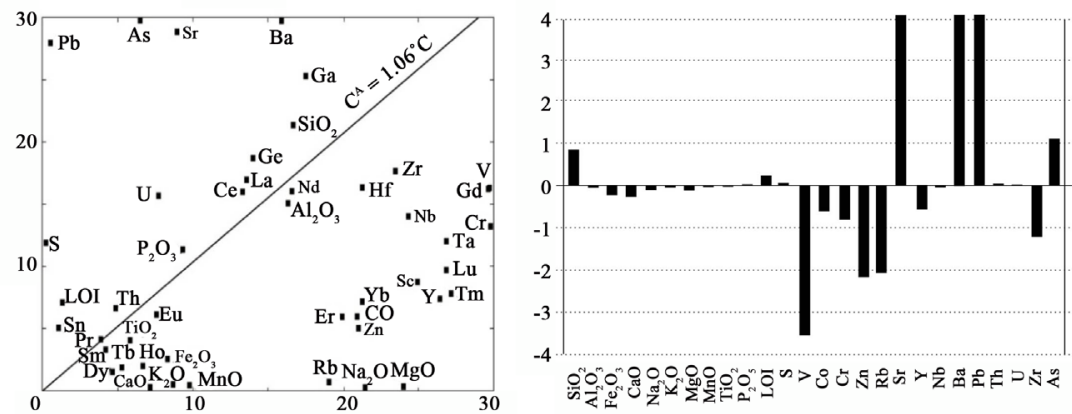

(b)
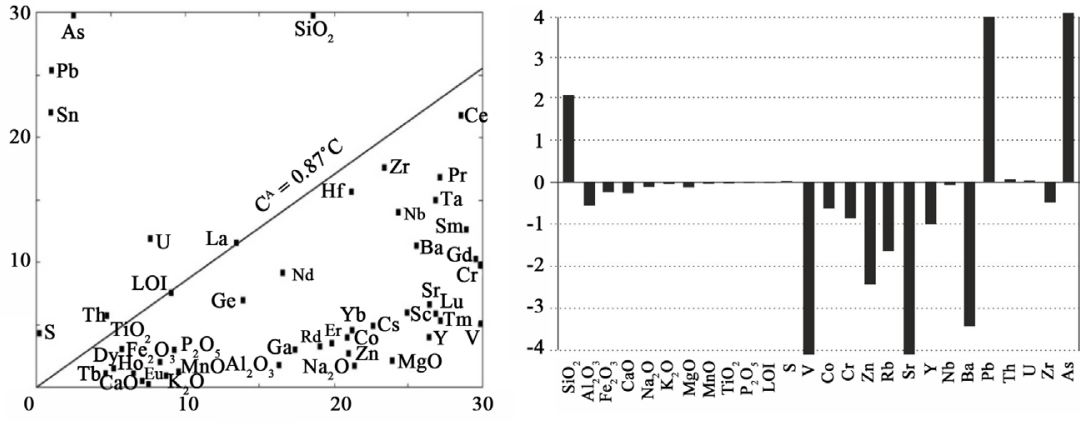

(c)

Figure 7. Isocon diagrams of three different alteration facies and histograms showing the percentage of gains and losses of selected elements during hydrothermal alteration as calculated from isocon method [35]. (a) argillic, (b) an advanced argillic, and (c) silicic alteration. Values of +4 to $+3=$ a gain of $75 \%$ to $100 \%,+3$ to $+2=50 \%$ to $75 \%,+2$ to $+1=$ $25 \%$ to $50 \%$, and +1 to $0=0 \%$ to $25 \%$ respectively, and $0=$ immobile elements. Values of 0 to $-1=$ losses of $0 \%$ to $25 \%,-1$ to $-2=25 \%$ to $50 \%,-2$ to $-3=50 \%$ to $75 \%$, and -3 to $-4=75 \%$ to $100 \%$.

In the argillic rocks, oxides and element such as $\mathrm{SiO}_{2}, \mathrm{~K}_{2} \mathrm{O}, \mathrm{Sn}, \mathrm{Tl}, \mathrm{Cs}, \mathrm{Y}, \mathrm{Pb}$, $\mathrm{Zr}$, As, and $\mathrm{S}$ are enriched, however, the remaining components are depleted (Figure 7(a)). The advanced argillic rocks show strong enrichments of As, Sr, $\mathrm{Ba}, \mathrm{Pb}$, and $\mathrm{SiO}_{2}$ (Figure 7(b)). The concentration of other oxides and elements such as $\mathrm{Sn}, \mathrm{Th}, \mathrm{P}_{2} \mathrm{O}_{5}, \mathrm{~S}$ and $\mathrm{U}$ are also slightly enriched whereas most major oxides $\left(\mathrm{K}_{2} \mathrm{O}, \mathrm{Al}_{2} \mathrm{O}_{3}, \mathrm{CaO}, \mathrm{MnO}, \mathrm{Na}_{2} \mathrm{O}, \mathrm{MgO}\right.$, and $\left.\mathrm{Fe}_{2} \mathrm{O}_{3}\right)$ and elements $(\mathrm{Nd}, \mathrm{Zr}$, $\mathrm{Nb}, \mathrm{Co}, \mathrm{Cr}, \mathrm{Y}, \mathrm{Zn}$, and $\mathrm{Sc}$ ) are depleted in the advanced argillic facies rocks. In the silicic alteration facies (Figure 7 (c)), except for $\mathrm{SiO}_{2}, \mathrm{As}, \mathrm{Pb}, \mathrm{Sn}, \mathrm{U}$, Th and $\mathrm{S}$, other oxides and elements are strongly removed from the rocks. The anomalous concentration of arsenic is observed in this facies rocks. 


\section{Conclusions}

Based on the currently available data, the following summary and conclusions were made to interpret the development of hydrothermal system, and the REE behavior in different alteration facies of the Cijulang area:

A characteristic alteration sequence and zonation of an advanced argillic, argillic and propylitic alteration outward from the silicic core has developed from the progressive cooling and neutralization of hot acidic magmatic fluid with the host rocks. Silicic alteration facies is identified by the presence of residual and amorphous silica. All REE are strongly depleted in the silicic facies and a remarkable depletion of REE in this facies is probably caused by high acidity and abundance of $\mathrm{SO}_{4}^{2-}$ ion and $\mathrm{Cl}^{-}$and $\mathrm{F}^{-}$complexing ions in the hydrothermal solutions. Advanced argillic alteration facies is mineralogically composed of variable amounts of quartz, pyrophyllite, alunite, dickite, kaolinite and diaspore. The enrichment of LREE along with depletion of HREE is observed in this facies. The immobile nature of LREE might be caused by the bounding of these elements into alunite structure. This confirms an important role of the occurrences of secondary minerals which control the behavior of REE in the hydrothermal paragenesis. The major constituents of argillic facies are quartz, illite, smectite, and pyrite. The relative immobility of REE in this facies is possibly related to the higher $\mathrm{pH}$ and lower water/rock ratio. The presence of phyllosilicates such as kaolinite, smectite and illite/sericite could also be a possible factor to fix the REE into their structures. Mass balance calculation indicates that REE are relatively mobile in the silicic facies whereas they are immobile in both advanced argillic and argillic facies.

The result of the study shows how REE behavior in the hydrothermal alteration paragenesis gives important information concerning to the physico-chemical conditions during the leaching processes. A strong variability of LREE, MREE and HREE concentrations of different alteration facies indicates variable degree of alteration and different fluid/rock ratios. It shows the selective nature of REE and trace elements even under strongly acidic conditions. The results also represent a useful tool to study HS epithermal ore deposits because it helps understand the mechanisms during the development of 'main stage hypogene wall-rock alteration.

\section{Acknowledgements}

This research was financially supported by AUN/SEED-Net and JICA. The authors acknowledge the members of GeoMin Unit, PT Aneka Tambang Tbk for their support during field investigation in the Cijulang area.

\section{Conflicts of Interest}

The authors declare no conflicts of interest regarding the publication of this paper. 


\section{References}

[1] Michard, A. (1989) Rare Earth Element Systematics in Hydrothermal Fluid. Geochimicaet Cosmochimica Acta, 53, 745-750. https://doi.org/10.1016/0016-7037(89)90017-3

[2] Lewis, A.J., Palmer, M.R., Sturchio, N.C. and Kemp, A.J. (1997) The Rare Earth Element Geochemistry of Acid-Sulphate and Acid-Sulphate-Chloride Geothermal Systems from Yellowstone National Park, Wyoming, USA. Geochimicaet Cosmochimica Acta, 61, 695-706. https://doi.org/10.1016/S0016-7037(96)00384-5

[3] Alderton, D.H.M., Pearce, J.A. and Potts, P.J. (1980) Rare Earth Element Mobility during Granite Alteration: Evidence from Southeast England. Earth and Planetary Science Letters, 49, 149-165. https://doi.org/10.1016/0012-821X(80)90157-0

[4] Taylor, R.P. and Fryer, B.J. (1982) Rare Earth Element Geochemistry as an Aid to Interpreting Hydrothermal Ore Deposits. In: Evans, A.M., Ed., Metallization Associated with Acid Magmatism, John Wiley, New York, 57-365.

[5] Taylor, R.P. and Fryer, B.J. (1983) Rare Earth Element Lithogeochemistry of Granitoid Mineral Deposits. Bulletin of Canadian Institute Mine Metallurgy, 76, 74-84.

[6] Palacios, C.M., Hein, U.F. and Dulski, P. (1986) Behaviour of Rare Earth Elements during Hydrothermal Alteration at the Buena Esperanza Copper-Silver Deposit, Northern Chile. Earth and Planetary Science Letters, 80, 208-216. https://doi.org/10.1016/0012-821X(86)90105-6

[7] Lottermoser, B.G. (1990) Rare Earth Element and Heavy Metal Behaviour Associated with the Epithermal Gold Deposit on Lihir Island, Papua New Guinea. Journal of Volcanology and Geothermal Research, 40, 269-289. https://doi.org/10.1016/0377-0273(90)90109-S

[8] Hopf, S. (1993) Behaviour of Rare Earth Elements in Geothermal Systems of New Zealand. Journal of Geochemical Exploration, 47, 333-357. https://doi.org/10.1016/0375-6742(93)90075-W

[9] Arribas, A.J., Cunningham, C.G., Rytuba, J.J., Rye, R.O., Kelly, W.C., Podwisocki, M.H., McKee, E.H. and Tosdal, R.M. (1995) Geology, Geochronology, Fluid Inclusions, and Isotope Geochemistry of the Rodalquilar Gold Alunite Deposit, Spain. Economic Geology, 90, 795-822. https://doi.org/10.2113/gsecongeo.90.4.795

[10] Fulignati, P., Gioncada, A. and Sbrana, A. (1999) Rare Earth Element (REE) Behaviour in Alteration Facies of the Active Magmatic-Hydrothermal System of Volcano (Aeolin Island, Italy). Journal of Volcanology and Geothermal Research, 88, 325-342. https://doi.org/10.1016/S0377-0273(98)00117-6

[11] Salvi, S., Fontan, F., Monchoux, P., Williams-Jones, A.E. and Moine, B. (2000) Hydrothermal Mobilization of High Field Strength Elements in Alkaline Igneous Systems: Evidence from the Tamazeght Complex (Morocco). Economic Geology, 95, 559-576. https://doi.org/10.2113/gsecongeo.95.3.559

[12] Jiang, N., Sun, S., Chu, X., Mizuta, T. and Ishiyama, D. (2003) Mobilization and Enrichment of High-Field Strength Elements during Late- and Post-Magmatic Processes in the Shuiquangousyenitic Complex, Northern China. Chemical Geology, 200, 117-128. https://doi.org/10.1016/S0009-2541(03)00162-1

[13] Karakaya, N. (2009) REE and HFS Element Behavior in the Alteration Facies of the ErenlerDaği Volcanics (Konya, Turkey) and Kaolinite Occurrence. Journal of Geochemical Exploration, 101, 185-208. https://doi.org/10.1016/j.gexplo.2008.07.001

[14] Parsapoor, A., Khalili, M. and Mackizadeh, M.A. (2009) The Behaviour of Trace and Rare Earth Elements (REE) during Hydrothermal Alteration in the Rangan 
Area (Central Iran). Journal of Asian Earth Sciences, 34, 123-134. https://doi.org/10.1016/j.jseaes.2008.04.005

[15] Küpeli, Ş. (2010) Trace and Rare-Earth Element Behavior during Alteration and Mineralization in the Attepe Iron Deposits (Feke-Adana, Southern Turkey). Journal of Geochemical Exploration, 105, 51-74. https://doi.org/10.1016/j.gexplo.2010.04.001

[16] Karakaya, M.Ç., Karakaya, N., Küpeli, Ş. and Yavuz, F. (2012) Ore Geology. Reviews, 48, 197-224. https://doi.org/10.1016/j.oregeorev.2012.03.007

[17] Lottermoser, B.G. (1992) Rare Earth Element and Hydrothermal Ore Formation Processes. Ore Geology Reviews, 7, 25-41. https://doi.org/10.1016/0169-1368(92)90017-F

[18] Wood, S.A. (1990) The Aqueous Geochemistry of the Rare Earth Elements and Yttrium: Theoretical Prediction in Hydrothermal Solutions to $350{ }^{\circ} \mathrm{C}$ at Saturation of Water Vapour Pressure. Chemical Geology, 88, 99-125. https://doi.org/10.1016/0009-2541(90)90106-H

[19] Haas, J.R., Shock, E.L. and Sassani, D.C. (1995) Rare Earth Elements in Hydrothermal Systems: Estimates of Standard Partial Modal Thermodynamic Properties of Aqueous Complexes of the Rare Earth Elements at High Pressures and Temperatures. Geochimicaet Cosmochimica Acta, 59, 4329-4350. https://doi.org/10.1016/0016-7037(95)00314-P

[20] Pirajno, F. (1992) Hydrothermal Mineral Deposits. John Wiley and Sons, Sydney, 709 p. https://doi.org/10.1007/978-3-642-75671-9

[21] Takahashi, Y., Tada, A. and Shimizu, H. (2004) Distribution of Pattern of Rare Earth Ions between Water and Montmorillonite and Its Relation to the Sorbed Species of the Ions. Analytical Sciences, 20, 1301-1306. https://doi.org/10.2116/analsci.20.1301

[22] Carlile, J.C. and Mitchell, A.H.G. (1994) Magmatic Arcs and Associated Gold Copper Mineralization in Indonesia, Journal of Geochemical Exploration, 50, 91-142. https://doi.org/10.1016/0375-6742(94)90022-1

[23] Hamilton, W.H. (1979) Tectonics of the Indonesian Region. USGS Professional Paper, 1078, 345 p. https://doi.org/10.3133/pp1078

[24] Rangin, C., Jolivet, L. and Pubellier, M. (1990) A Simple Model for the Tectonic Evolution of Southeast Asia and the Indonesian Region for the Past 43 m.y. Bulletin de la Société Géologique de France, 8, 889-905. https://doi.org/10.2113/gssgfbull.VI.6.889

[25] Whitford, D.J., Nicholls, I.A. and Taylor, S.R. (1979) Spatial Variations in the Geochemistry of Quaternary Lavas across the Sunda Arc in Java and Bali. Contributions to Mineralogy and Petrology, 70, 341-356. https://doi.org/10.1007/BF00375361

[26] Katili, J.A. (1989) Evolution of the Southeast Asian Arc Complex. Indonesian Geology, 12, 113-143.

[27] Nicholls, I.A., Whitford, D.J., Harris, K.L. and Taylor, S.R. (1980) Variation in the Geochemistry of Mantle Source for Tholeitic and Calc-Alkaline Mafic Magma, Western Sunda Volcanic Arc, Indonesia. Chemical Geology, 30, 177-199. https://doi.org/10.1016/0009-2541(80)90105-9

[28] Soeria-Atmadja, R., Maury, R.C., Bellon, H., Pringgoprawiro, H., Polve, M. and Priadi, B. (1994) Tertiary Magmatic Belts in Java. Journal of Southeast Asian Earth Sciences, 9, 13-27. https://doi.org/10.1016/0743-9547(94)90062-0

[29] Van Bemmelen, R.W. (1949) The Geology of Indonesia, V.F.A. Government Print- 
ing Office, The Hague, 732 p.

[30] Martodjojo, S. (1984) Bogor Basin Evaluation, West Java (EvolusiCekungan Bogor, Jawa Barat). Doctoral Thesis, Institute of Technology of Bandung, Bandung, 238 p.

[31] Verdiansyah, O., Bangun, P. and Rahmat, I. (2012) High-Sulfidation Epithermal Gold Occurrences in Cijulang Area, Garut, West Java. 41 th IAGI Annual Convention and Exhibition, Yogyakarta, 17-20 September 2012.

[32] Tun, M.M., Warmada, I.W., Idrus, A., Harijoko, A., Al-Furqan, R. and Watanabe, K. (2015) Characteristics of Hydrothermal Alteration in Cijulang Area, West Java, Indonesia. Journal of Applied Geology, 7, 1-9.

[33] Stoffregen, R. (1987) Genesis of Acid-Sulfate Alteration and Au-Cu-Ag Mineralization at Summitville, Colorado. Economic Geology, 82, 1575-1591. https://doi.org/10.2113/gsecongeo.82.6.1575

[34] Sun, S.S. and McDonough, W.S. (1989) Chemical and Isotopic Systematic of Oceanic Basalts: Implications for Mantle Composition and Processes. In: Saunders, A.D. and Norry, M.J., Eds., Magmatism in the Ocean Basins, The Geological Society of London, London, Special Publication, 313-345.

https://doi.org/10.1144/GSL.SP.1989.042.01.19

[35] McLennan, S.M. (1989) Rare Earth Elements in Sedimentary Rocks: Influence of the Provenance and Sedimentary Process. Reviews in Mineralogy, 21, 169-200. https://doi.org/10.1515/9781501509032-010

[36] Knight, J.E. (1977) A Thermochemical Study of Alunite, Enargite, Luzonite, and Tennantite Deposits. Economic Geology, 72, 1321-1336. https://doi.org/10.2113/gsecongeo.72.7.1321

[37] Grant, J.A. (1986) The Isocon Diagram; a Simple Solution to Gresens' Equation for Metasomatic Alteration: Economic Geology, 81, 1976-1982. https://doi.org/10.2113/gsecongeo.81.8.1976

[38] Potdevin, J.L. (1993) Gresens 92: A Simple Macintosh Program of the Gresens Method. Computers and Geosciences, 19, 1229-1238. https://doi.org/10.1016/0098-3004(93)90027-3 